\title{
Opetusohjelmista yleisradiossa
}

Tampereella järjestettiin alkukesällä Euroopan Yleisradioliiton EBUn opetusohjelmajaoston kokous. Vuosikokous oli viisipäiväinen. Edustajia eri haista oli noin 70. Vuosikokouksessa käsiteltiin uusien teknisten välineiden vaikutusta opetusohjelmiin, rauhantyötä, kehitysmaiden erityisongelmia, EBUn jäsenten perinteistä yhteistyötä ja opetusohjelmien suuntaamista iäkkäämmille.

Yleisradion pääjohtaja Sakari Kiuru avasi päivät. Hän painotti puheessaan kansallisen omaleimaisuuden tärkeyttä myös kansainvälisessä yhteistyössä. Opetusohjelmien on aina otettava huomioon paikalliset olot. Yhteistyö ei saa olla esteenä omaleimaisuudelle.

Kiuru vaati varsinaisen asiaopetuksen rinnalle valikoimisen opettamista. Asiaopetus yksinään ei riitä. On opittava valikoimaan, suhtautumaan kriittisesti ja arvostelemaan ohjelmien kasvavaa tulvaa. Tämän valikoivan asenteen kehittämiseen Kiuru pyysi apua myös aikuiskasvatusjärjestöiltä.

Kiurun mukaan tekijänoikeuslain uudistus on helpottamassa suomalaisten opetusohjelmien tekoa. Uudistuksen mukaan on nyt kaikenlaisen ohjelman äänitys ja nauhoitus opetustarkoituksiin sallittua. Näin on mahdollista entistä joustavammin ja tehokkaammin toteuttaa opetusta esimerkiksi videonauhoitteiden avulla.

Donald Grattan BBC:n opetusohjelmista pohti uusien teknisten välineiden vaikutusta opetusohjelmiin. Satelliitteja hän ei pitänyt merkittävinä juuri opetusohjelmien kannalta, sillä satelliittien kohderyhmä on liian laaja ja epämääräinen. Ne sopivatkin paremmin viihdeohjelmien lähettämiseen. Sen sijaan Grattan kertoi siitä, miten pienoistietokoneet ovat uusi väline ja uusi mahdollisuus juuri opetukselle. Pienoistietokoneet voivat avata pelkästään kieleen ja sanoihin virheellisesti jähmettyneen opetuksen uusille aloille, hän täsmensi. Uudet viestimet ovat uhkan sijaan haaste opetuksen kehittymiselle ja uusiutumiselle.

Pääsihteeri Helena Kekkonen avasi EBUn keskustelulle uuden aihepiirin; rauhantyön. Hän näkee opetusohjelmissa tehokkaan vaikutuskanavan ihmisen sosiaaliselle kasvatukselle ja entistä kokonaisvaltaisemmalle rauhantyölle. Opetusohjelmien varsinaisten faktojen, tosiasioiden opettamisen lisäksi voidaan kohot- taa itsetuntoa, nostaa sosiaalista omatuntoa, poistaa ennakkoluuloja ja niin edelleen.

Professori Yrjö Littusen mukaan kehitysmaiden opetusohjelmien erityisongelmana on se, että länsimaat hoitavat käytännössä koko tietoliikenteen. Kehitysmaista saadaan tietoa äärimmäisen vähän. Myöskään kehitysmaat itse eivät siis saa tietoa omista elinoloistaan, vaan paljon tarpeetontakin tietoa länsimaista. Oman kulttuurin ja maan tuntemus jää kehittymättä. Tiedon puute on kaksiosainen. Tieto ei kulje kehitysmaista länsimaihin eikä kehitysmaiden sisällä.

EBUn jäsenten välinen yhteistyö eli kansainväliset yhteiset opetusohjelmat puhuttivat jälleen osanottajia. Kansainvälinen yhteistyö on ollut onnistunutta (esimerkkeinä meilläkin nähtävä Kiinasta kertova ohjelmasarja ja moninaiset kieltenopetuksen ohjelmat). Yhteistyön määrä kasvaa yhä.

Saksan liittotasavallan television Karl J. Jöressen kertoi iäkkäämmälle sukupolvelle tarkoitettujen opetusohjelmien tekemisestä. Monissa Euroopan maissa heidät on otettu omaksi erityiseksi kohderyhmäkseen. Jöressen täsmensi sitä, että eläkeläiset on saatava liikkeelle television takaa. Länsi-Saksassa perustettiin televisiossa nähdyn esimerkin mukaisia keskustelupiirejä 1800 kappaletta eri puolille maata. Niissä jatkettiin televisiossa nähtyä keskustelua, viihdyttiin yhdessä ja jatkettiin omalla ohjelmalla.

Jöressen ei pidä kuitenkaan uuden tiedon saamista kaikkein keskeisimpänä kysymyksenä eläkeläisille. Tärkeintä on hänen mielestään jo hankitun tiedon hyödyntäminen. Ihannetapauksessa tätä tietomäärää voisivat käyttää hyväkseen kaikki seuraavat sukupolvet. Iäkkäämpi sukupolvi voisi näin vaikuttaa myös tulevaan yhteiskuntaan. Koko elämän ajan kerätty tietomäärä käytettäisiin tehokkaasti.

Euroopan Yleisradioliiton EBUn opetusohjelmajaoston viisipäiväinen vuosikokous käsitteli suurimmaksi osaksi ennestään tuttuja ja moneen kertaan puhuttuja asioita. Varsinaisesti uutta tietoa oli kokouksessa tarjolla sangen niukasti. Uusia näkökulmia, selkeitä kannanottoja ja tiukempaa kritiikkiä - itsekritiikkiäkin - olisi tarvittu. Kiurun avajaispuheessaan kaipaamaa valikoivaa asennetta kaivattaisiin myös EBUn sisällä. 